\title{
MICHAELA VALENTE, La salvezza degli Stati: atei, streghe, infedeli ed eretici nel pensiero di Bodin
}

\section{Filippo Fassina}

\section{(2) OpenEdition}

\section{Journals}

\section{Edizione digitale}

URL: https://journals.openedition.org/studifrancesi/31538

DOI: 10.4000/studifrancesi.31538

ISSN: 2421-5856

\section{Editore}

Rosenberg \& Sellier

\section{Edizione cartacea}

Data di pubblicazione: 1 août 2020

Paginazione: 390

ISSN: 0039-2944

\section{Notizia bibliografica digitale}

Filippo Fassina, «michaela VAlente, La salvezza degli Stati: atei, streghe, infedeli ed eretici nel pensiero di Bodin», Studi Francesi [Online], 191 (LXIV | II) | 2020, online dal 01 septembre 2020, consultato il 16 septembre 2021. URL: http://journals.openedition.org/studifrancesi/31538 ; DOI: https://doi.org/ 10.4000/studifrancesi.31538

Questo documento è stato generato automaticamente il 16 septembre 2021.

\section{(c) (i) (9)}

Studi Francesi è distribuita con Licenza Creative Commons Attribuzione - Non commerciale - Non opere derivate 4.0 Internazionale. 


\title{
MICHAELA VALENTE, La salvezza degli Stati: atei, streghe, infedeli ed eretici nel pensiero di Bodin
}

\author{
Filippo Fassina
}

\section{NOTIZIA}

MICHAELA VALENTE, La salvezza degli Stati: atei, streghe, infedeli ed eretici nel pensiero di Bodin, “Bibliothèque d'Humanisme et Renaissance", LXXXI-2, 2019, pp. 291-308.

1 La produzione di Jean Bodin si inserisce all'interno di un contesto storico e culturale che vede, nella prima metà del Cinquecento, in gran parte degli stati europei, la nascita di una politica di repressione della libertà religiosa. Tale produzione abbraccia svariati ambiti, da quello teologico a quello politico, ambiti all'interno dei quali ha un ruolo centrale la questione della tolleranza religiosa e la difesa della libertà di coscienza. In primo luogo, viene analizzata la sua opera République, in cui viene proposta l'idea di una pace civile che possa porre fine alle guerre che minano la stabilità europea. In particolare, Bodin individua nella monarchia il mezzo migliore per consentire la tolleranza, poiché il sovrano si pone come arbitro e giudice fra le tesi contrastanti in ambito religioso. Il re deve infatti evitare in ogni modo che si diffondano i germi dell'ateismo, considerato la peggiore minaccia per la stabilità dello Stato, ancora più pericolosa della tirannide e della superstizione. Viene sottolineato come Bodin affermi che è impossibile usare la coercizione in materia di coscienza, altrimenti si provocano danni sia a livello politico sia a livello sociale. Nell'opera Démonomanie, rivolgendosi a un pubblico più ampio, si tocca un argomento più complesso, quello di demoni $\mathrm{e}$ streghe, considerati una punizione divina, in quanto la macchinazione diabolica attecchisce laddove il sovrano non osserva i confini dell'autorità divina e della filosofia naturale. Chi si vota al demonio infatti provoca gravi effetti sull'intera società e incrementa l'ateismo. A questa piaga l'unico rimedio è la fede, vista come instrumentum 
regni, in quanto riesce a esercitare un controllo sull'individuo senza limitare la libertà personale. Tuttavia, anche il passaggio da una fede all'altra è visto negativamente, poiché lascia spazio all'ateismo e permette che si insinuino il dubbio e lo scetticismo, nemici della religione. Infine, viene analizzato il Colloquium Heptaplomeres, un dialogo fra sette esponenti di fedi e religioni diverse che si svolge a Venezia. Attraverso i protagonisti, Bodin ribadisce ancora la necessità di difendere la stabilità politica escludendo rimedi repressivi e promuovendo la tolleranza e il pluralismo. 